\title{
STUDI PERATURAN DAERAH KOTA SERANG NOMOR 6 TAHUN 2014 TENTANG PENGELOLAAN ZAKAT: PERSPEKTIF EFEKTIFITAS DAN KAPASITAS
}

\section{STUDY OF REGIONAL REGULATION OF SERANG CITY NUMBER 6 YEAR 2014 ABOUT ZAKAT MANAGEMENT: EFFECTIVENESS AND CAPACITY PERSPECTIVE}

\author{
Muhammad Kamil Husain \\ Universitas Serang Raya \\ Corresponding Author E-mail: kamilhusain74@yahoo.com
}

\begin{abstract}
Abstrak
Tujuan penelitian ini menganalisis bagaimana studi Perda Nomor 6 tahun 2014 Kota Serang tentang pengelolaan zakat dalam perspektif efektifitas dan kapasitas berdasarkan kapasitas kelembagaan, kebijakan/regulasi, perubahan system implementasi dan derajat perubahan kelompok sasaran. Metode penelitian yang digunakan adalah pendekatan kualitatif. Teknik yang dilakukan oleh peneliti adalah survei literatur akademis. Teknik pengumpulan data dilakukan melalui penelusuran berbagai sumber dan literatur baik dari dokumen pemerintah dan media massa elektronik, jurnal dan buku-buku yang terkait dengan Perda Kota Serang Nomor 6 tahun 2014 tentang pengelolaan zakat. Hasil penelitian menunjukkan bahwa efektifitas dan kapasitas Peraturan Daerah Kota Serang Nomor 6 tahun 2014 tentang pengelolaan zakat sudah cukup memadai dan dalam implementasinya, kapasitas konten Perda sudah mengatur penyelenggaraan zakat dengan melibatkan partisipasi masyarakat serta menjadi menjadi instrument penting penerimaan zakat meskipun diperlukan penguatan pada aspek kelembagaan dan inovasi pengumpulan dan distribusi zakat yang efektif dan produktif.
\end{abstract}

Kata Kunci: Zakat, Kota Serang, Efektivitas, Kapasitas.

\begin{abstract}
Abstrak
The purpose of this research is to analyze how the study of Perda No. 6/2014 on the City of Serang on zakat management from the perspective of effectiveness and capacity based on institutional capacity, policies / regulations, changes in implementation systems and the degree of change in target groups. The research method used is a qualitative approach. The technique used by researchers is a survey of the academic literature. The data collection technique is carried out by searching various sources and literature from both government documents and electronic mass media, journals and books related to Perda Kota Serang Number 6 of 2014 concerning zakat management. The results show that the effectiveness and capacity of the Regional Regulation of the City of Serang Number 6 of 2014 concerning zakat management is sufficient and in its implementation, the capacity of the content of the Perda has regulated the implementation of zakat by involving community participation and has become an important instrument for receiving zakat although it is necessary to strengthen the institutional and innovation in the collection and distribution of zakat that is effective and productive.
\end{abstract}

Keywords: Zakat, City of Serang, Effectiveness, Capacity 
Jurnal Administrasi Negara

ISSN : 2598-4039 (Online)

ISSN : 2302-2231 (Print)
Muhammad Kamil Husain

Universitas Serang Raya

\section{PENDAHULUAN}

Kesejahteraan masyarakat dan kemiskinan merupakan fenomena yang nyata dan masih menjadi problem yang belum terselesaikan hingga saat ini. Di sisi lain pemerintah telah berupaya melakukan berbagai kebijakan distributif dan alokasi sumber daya guna memastikan peningkatan taraf hidup masyarakat. Berbagai penelitian menunjukkan bahwa terdapat hubungan kausalitas yang menjadi penyebab belum terwujudnya kesejahteraan masyarakat dan kemiskinan yaitu factor alamiah seperti keterbatasan ekonomi dan ilmu pengetahuan masyarakat dan factor non alamiah seperti kebijakan sosial dan ekonomi pemerintah yang masih belum ideal dan sesuai dengan harapan masyarakat.

Kebijakan sosial dan ekonomi yang memiliki keterkaitan erat dengan kebutuhan masyarakat adalah zakat sebagai instrumen ekonomi yang tidak terpisahkan dalam pembangunan karena mampu mengharmonisasikan jaminan sosial dengan mengurangi kesenjangan antara mereka yang berpenghasilan tinggi dengan yang berpenghasilan rendah (Takril \& Othman, 2020). Sesungguhnya zakat tidak hanya merupakan tuntutan secara individual akan tetapi tuntutan kepada pemerintah/penguasa dalam bentuk regulasi yang disusun secara sistematis (Qardhawi, 1999). Oleh karena itu zakat dipandang sebagai jaminan sosial yang bertujuan untuk mendorong dan membantu orang-orang yang membutuhkan dari kalompok lemah dan fakir (Quthub, 1992). Penyelenggaraan zakat dalam berbagai aspek sudah sudah mengalami perbaikan baik dari segi infrastruktur, sumber daya manusia, sistem distribusi dan transparansi tata kelola, meskipun masih terdapat beberapa permasalahan yang perlu diatasi untuk memastikan penyelenggaraan zakat berjalan sesuai dengan regulasi yang berlaku (Ab Rahman et al., 2012), dalam hal ini factor regulasi atau peraturan zakat yang tidak efektif dapat menjadi penghambat penyelenggaraan sistem zakat (Khasandy et al., 2019).

Instrument zakat sebagai lembaga yang fokus pada sector non profit di mana dana dikumpulkan dan kemudian didistribusikan kembali ke penerima (Said et al., 2012) dalam konteks Kota Serang Provinsi Banten diatur melalui Peraturan Daerah (Perda) Nomor 6 Tahun 2014 tentang pengelolaan zakat berdasarkan Undang-undang Nomor 38 Tahun 1999 tentang pengelolaan zakat. Disebutkan bahwa pengelolaan zakat adalah kegiatan perencanaan, pelaksanaan, dan pengoordinasian dalam pengumpulan, pendistribusian, dan pendayagunaan zakat dengan tujuan untuk meningkatkan efektivitas dan efisiensi pelayanan serta meningkatkan manfaat zakat untuk mewujudkan kesejahteraan masyarakat dan penanggulangan kemiskinan 
Jurnal Administrasi Negara

ISSN : 2598-4039 (Online)

ISSN : 2302-2231 (Print)
Muhammad Kamil Husain

Universitas Serang Raya dengan berasaskan syariat islam, amanah, kemanfaatan, keadilan, kepastian hukum, terintegritas dan akuntabilitas.

Badan Amil Zakat Nasional (Baznas) Kota Serang merupakan lembaga yang berwenang melakukan tugas pengelolaan zakat di daerah dan memiliki fungsi perencanaan, pelaksanaan dan pengendalian dalam upaya pengumpulan, pendistribusian, dan pendayagunaan zakat serta melakukan pelaporan dan pertanggungjawaban pelaksanaan pengelolaan zakat. Pengelolaan zakat Baznas Kota Serang terdiri atas unsur pimpinan dan pelaksana dan dalam implementasinya dapat melakukan pengumpulan zakat secara langsung atau membentuk UPZ atau Unit Pengelola Zakat pada a)kantor satuan kerja pemerintah daerah; b)kantor instansi vertikal; c)badan usaha milik daerah; d)perusahaan swasta; e)masjid, mushalla, langgar, surau atau nama lainnya; f)sekolah/madrasah dan lembaga pendidikan lain; g)kecamatan atau nama lainnya; dan h)kelurahan yang bertugas membantu pengumpulan zakat dimana hasil pengumpulan zakat wajib disetorkan ke Baznas Kota Serang. Selain itu masyarakat dapat berpartisipasi dengan membentuk LAZ atau Lembaga Amil Zakat yang membantu pelaksanaan pengumpulan, pendistribusian, dan pendayagunaan zakat

Berdasarkan data empiris penelitian, implementasi pengelolaan zakat di Kota Serang yang diatur melalui Perda Nomor 6 Tahun 2014 tentang pengelolaan zakat sudah melibatkan partisipasi masyarakat dan berjalan sesuai dengan regulasi, akan tetapi secara implementatif Perda tersebut belum mampu menjadi instrument yang dapat menyelesaikan permasalahan zakat secara komprehensif, berbagai factor penyebab seperti Perda Kota Serang Nomor 6 tahun 2014 tentang pengelolaan zakat masih mengacu kepada Undang-undang Nomor 38 tahun 1999 tentang pengelolaan zakat, sedangkan undang-undang yang sekarang berlaku adalah Undangundang Nomor 23 tahun 2011 (Mediatama, 2019). Selain itu masih terdapat beberapa permasalahan seperti masih rendahnya kesadaran masyarakat untuk membayar zakat sehingga menyulitkan Baznas Kota Serang menarik zakat dari masyarakat, proporsi perolehan zakat yang tidak seimbang antara masyarakat dan Aparatur Sipil Negara (ASN) dan pendapatan zakat lebih didominasi oleh Aparatur Sipil Negara (ASN) Pemerintahan Kota Serang (Mediatama, 2019). Dan berikut ini adalah grafik penerima dana zakat Baznas Kota Serang dalam kurun waktu 2014-2019. 
Jurnal Administrasi Negara

ISSN : 2598-4039 (Online)

ISSN : 2302-2231 (Print)
Muhammad Kamil Husain

Universitas Serang Raya

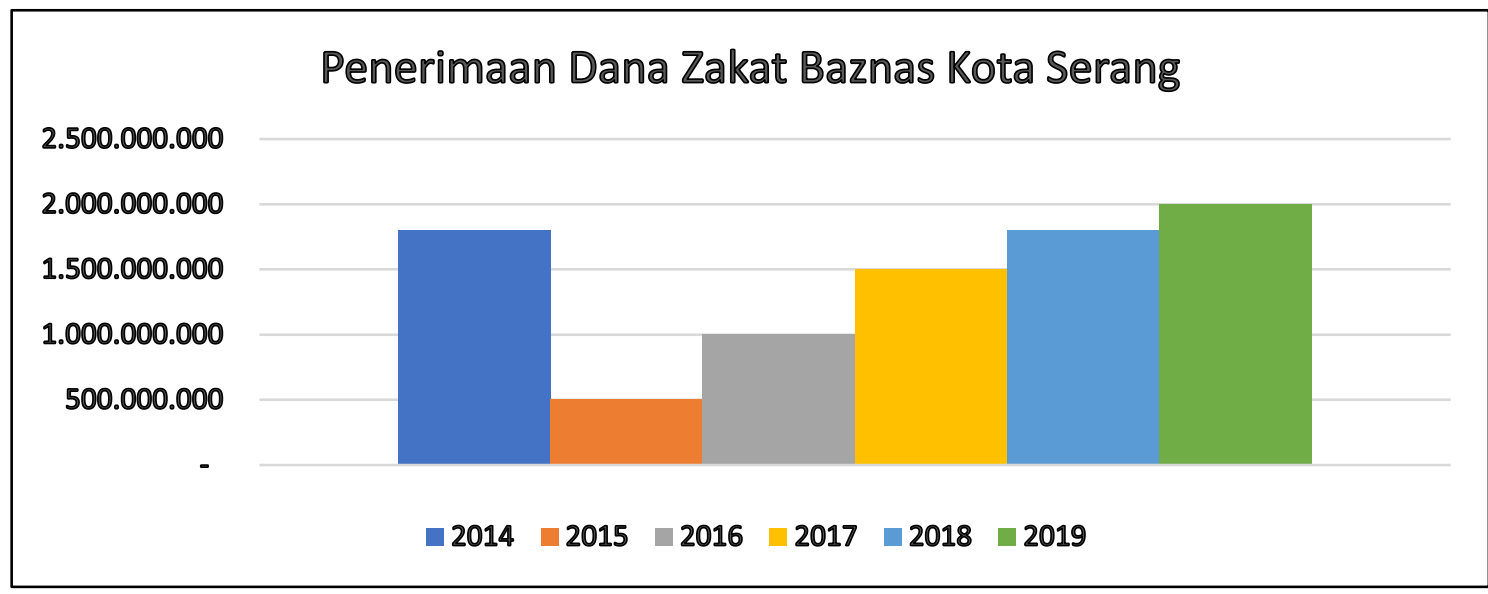

Gambar 1 Penerimaan Dana Zakat Kota Serang, 2014-2019

Sumber : Baznas Kota Serang, diolah Peneliti, 2020.

Berdasarkan gambar 1 di atas, maka dapat dideskripsikan bahwa penerimaan zakat di Kota Serang cenderung mengalami fluktuatif, hal ini disebabkan karena beberapa permasalahan yang telah diuraikan sebelumnya. Meskipun demikian terdapat fenomena yang menarik yaitu meningkatnya penerimaan zakat di Kota Serang disebabkan adanya aturan dari Walikota Serang yang mengatur pemotongan gaji ASN setiap bulannya untuk alokasi zakat.

Selanjutnya, penelitian ini akan menguraikan beberapa penelitian terdahulu yang berkaitan dengan pengelolaan zakat. Penelitian tentang efektifitas zakat yang dilakukan oleh (Takril \& Othman, 2020) menunjukkan masih belum efektifnya distribusi zakat yang disebabkan factor-faktor tertentu. Selanjutnya (Said et al., 2012) dalam penelitiannya mengusulkan pengukuran kinerja dapat digunakan organisasi zakat melalui indeks keuangan, indeks pegawai, indeks penerima zakat dan indeks pembayar zakat, kemudian (Lubis \& Azizah, 2018) mengatakan terdapat potensi yang besar dalam Sistem Pengelolaan Zakat untuk meningkatkan kesejahteraan masyarakat sehingga memerlukan perhatian pemerintah sehingga penggunaan teknologi yang tepat dalam pengelolaan zakat menjadi penting dalam upaya meningkatkan efisiensi dan mengoptimalkan potensizakat, oleh karena itu, beberapa faktor terkait harus dipertimbangkan seperti sumber daya manusia, lingkungan, budaya, bahasa, literasi dan regulasi untuk meningkatkan efektivitas interaksi dan komunikasi antar pemangku kepentingan

Perspektif berbeda tentang penelitian tentang zakat dilakukan oleh (Ali \& Hatta, 2014) yang membandingkan pengelolaan di tiga 
Jurnal Administrasi Negara

ISSN : 2598-4039 (Online)

ISSN : 2302-2231 (Print)
Muhammad Kamil Husain

Universitas Serang Raya negara muslim yaitu Bangladesh, Malaysia dan Indonesia. Dalam hasil penelitiannya menyebutkan Malaysia merupakan negara yang memiliki tingkat keberhasilan pengelolaan zakat yang sangat baik karena didukung oleh badan yang kompeten dan keserusan pemerintah, sedangkan Indonesia termasuk negara dengan pengelolaan zakat yang kurang ideal dikarenakan praktek-praktek korupsi dan mis management dalam implementasinya sedangkan Bangladesh merupakan negara dengan tingkat keseriusan rendah dalam pengelolaan zakat dikarenkan belum ada inisiatif dari pemerintah.

Beberapa penelitian yang telah diuraikan di atas menunjukkan adanya kesamaan kesamaan tema yaitu pengelolaan zakat dalam berbagai perspektif, akan tetapi penelitian tentang pengelolaan zakat berdasarkan studi Perda Nomor 6 tahun 2014 di Kota Serang yang dianalisis dalam perspektif efektifitas dan kapasitas belum dilakukan secara mendalam.

Indicator

efektivitas

implementasi sebagaimana dikemukakan oleh (Sandfort \& Moulton, 2015) didefinisikan sebagai kapasitas perubahan system implementasi dan derajat perubahan kelompok sasaran. Selanjutnya menurut (Howlett \& Lindquist, 2014, hal. 225) efektifitas implementasi relevan dengan kapasitas kebijakan yang dibutuhkan untuk memotret lingkungan dan menetapkan arah strategis, sedangkan dalam perspektif lainnya, kapasitas kebijakan dimaknai sebagai suatu upaya untuk menimbang dan menilai implikasi dari alternatif kebijakan (Bakvis, 2000, hal. 71).

Pandangan yang memiliki kesesuaian sepert di atas dikemukakan oleh (Wu et al., 2015, hal. 1) yang mengatakan bahwa efektifitas implementasi suatu regulasi atau kebijakan memiliki keterkaitan erat dengan kapasitas kebijakan yang didefinisikan sebagai keterampilan dan sumber daya yang diperlukan dalam menjalankan fungsi kebijakan. Sehingga dapat didefinisikan bahwa kapasitas kebijakan adalah fungsi dari tiga keterampilan dan kompetensi (politik, operasional, dan analitis) dan tiga tingkat sumber daya dan kapabilitas (sistemik, organisasi, dan individu) yang menghasilkan sembilan jenis kapasitas kebijakan (Wu et al., 2015, hal. 3). 
Jurnal Administrasi Negara

ISSN : 2598-4039 (Online)

ISSN : 2302-2231 (Print)
Muhammad Kamil Husain

Universitas Serang Raya

Tabel 1 Policy Capacity: Skills and Resources

\begin{tabular}{|c|c|c|c|}
\hline Levels of & \multicolumn{3}{|c|}{ Skills and Competences } \\
\hline $\begin{array}{c}\text { Resources and } \\
\text { Capabilities }\end{array}$ & Analytical & Managerial & Political \\
\hline Individual & $\begin{array}{l}\text { Individual Analytical } \\
\text { Capacity }\end{array}$ & $\begin{array}{l}\text { Individual Managerial } \\
\text { Capacity }\end{array}$ & $\begin{array}{l}\text { Individual Political } \\
\text { Capacity }\end{array}$ \\
\hline Organizational & $\begin{array}{l}\text { Organizational } \\
\text { Analytical Capacity }\end{array}$ & $\begin{array}{l}\text { Organizational } \\
\text { Managerial Capacity }\end{array}$ & $\begin{array}{l}\text { Organizational } \\
\text { Political Capacity }\end{array}$ \\
\hline Systemic & $\begin{array}{l}\text { Systemic Analytical } \\
\text { Capacity }\end{array}$ & $\begin{array}{l}\text { Systemic Managerial } \\
\text { Capacity }\end{array}$ & $\begin{array}{l}\text { Systemic } \\
\text { Capacity }\end{array}$ \\
\hline
\end{tabular}

Sumber : (Wu et al., 2015, hal. 3)

Seperti yang ditunjukkan pada tabel di atas terdapat tiga dimensi kapasitas kebijakan yaitu: analitis (menilai dan membuat pilihan berdasarkan informasi), manajerial (melaksanakan keputusan) dan politik (berinteraksi dengan aktor kebijakan lain). Kerangka umum memperlihatkan kapasitas kebijakan tidak hanya melibatkan kategorisasi sumber daya dan kapabilitas multi level - individu, organisasi dan sistemik - tetapi juga interaksi dinamis dari setiap level tersebut

Tujuan penelitian ini menganalisis bagaimana studi Perda Nomor 6 tahun 2014 Kota Serang tentang pengelolaan zakat dalam perspektif efektifitas dan kapasitas. Artikel ini pada bagian awal terdiri dari pendahuluan dan metode penelitian. Kemudian pada bagian selanjutnya akan dilakukan hasil dan pembahasan dengan mengadaptasi teori yang dikemukakan oleh (Sandfort \& Moulton, 2015) dan (Wu et al., 2015, hal. 1) yang terdiri dariefektifitas dan kapasitas kelembagaan, kebijakan/regulasi, perubahan system implementasi dan derajat perubahan kelompok sasaran.

\section{METODE PENELITIAN}

Metode penelitian yang digunakan adalah pendekatan kualitatif. Teknik yang dilakukan oleh peneliti adalah survei literatur akademis. Teknik pengumpulan data dilakukan melalui penelusuran berbagai sumber dan literatur baik dari dokumen pemerintah dan media massa elektronik, jurnal dan buku-buku yang terkait dengan Perda Kota Serang Nomor 6 tahun 2014 tentang pengelolaan zakat. Data sekunder tersebut diolah dan dideskripsikan dalam bentuk narasi sesuai dengan kebutuhan data. Selanjutnya dilakukan 
Jurnal Administrasi Negara

ISSN : 2598-4039 (Online)

ISSN : 2302-2231 (Print)
Muhammad Kamil Husain

Universitas Serang Raya proses analisis data berdasarkan teori dan konsep serta selanjutnya dilakukan proses intrepretasi data.

\section{HASIL DAN PEMBAHASAN}

\section{- Efektifitas dan Kapasitas Kelembagaan}

Hasil penelitian menunjukkan bahwa kewenangan pengelola zakat di Kota Serang sebagaimana diatur dalam Perda Nomor 6 Tahun 2014 tentang pengelolaan zakat adalah Badan Amil Zakat Nasional (Baznas) Daerah Kota Serang sebagai leading sector atau lembaga resmi yang melakukan pengelolaan zakat di Daerah; dan dibantu oleh 2)Unit Pengumpul Zakat (UPZ) yang dibentuk oleh Baznas Daerah; dan 3)Lembaga Amil Zakat (LAZ) sebagai perwujudan partisipasi masyarakat.

Kredibilitas lembaga zakat dipengaruhi oleh persepsi pengguna jasa. Untuk pengguna layanan, ada dua jenis. Pertama, ada pembayar zakat yang membayar zakat dan berharap dana yang dibayarkan akan tersalurkan dengan baik. Kedua, ada penerima zakat yang menerima dana dan berharap mendapatkan dana zakat yang cukup (Wahab et al., 2016). Dan Kepuasan kedua pemangku kepentingan ini penting untuk memastikan lembaga zakat menjadi lembaga yang terpercaya (Adiwijaya \& Suprianto, 2020).

Dalam konteks efektifitas, perbedaan kelembagaan dapat menciptakan sinergitas dalam mewujudkan tujuan kebijakan dan organisasi. Sebagaimana dikemukakan oleh (Noor et al., 2015) bahwa perbedaan struktur kelembagaan dapat berperan penting dalam mempengaruhi kinerja lembaga, dengan kerjasama secara komprehensif dapat menghasilkan kinerja yang lebih baik dibandingkan kerjasama secara parsial. Sinergitas Baznas, UPZ dan LAZ dalam melakukan pengumpulan zakat dapat dilakukan melalui kerjasama yang dilakukan secara transparan dan akuntabel serta saling melengkapi.

Kapasitas kelembagaan Baznas daerah Kota Serang sebagai leading sector dapat menjadi keunggulan dalam membangun jaringan dan negoisasi dengan berbagai pihak untuk mengoptimalkan penerimaan zakat dan LAZ sebagai Lembaga di luar pemerintahan dapat berperan sebagai supporting dan menghimpun dana zakat dari sumber-sumber yang belum digali oleh Baznas daerah. Meskipun terdapat kecenderungan adanya keunggulan dari lembaga penghimpun zakat swasta seperti LAZ dibandingkan lembaga publik, seperti yang ditunjukkan oleh contoh Indonesia dan negara-negara di dunia (Bremer, 2013) akan tetapi Baznas Daerah sebagai Lembaga resmi pemerintah harus dapat melakukan penguatan kelembagaan sebagai Lembaga yang mampu mencapai target dan realisasi penerimaan zakat.

Bahwa masih terdapat permasalahan pada pencapaian target dan realisasi yang belum tercapai sehingga 
Jurnal Administrasi Negara

ISSN : 2598-4039 (Online)

ISSN : 2302-2231 (Print)
Muhammad Kamil Husain

Universitas Serang Raya mendorong inovasi kebijakan publik sebagai sebuah keniscayaan secara prinsip dan substantif akan memberikan penguatan dalam merespon dan menyelesaikan problematika yang berlangsung di tengah masyarakat dan kelembagaan menjadi suatu keniscayaan (Sururi, 2016). Dengan demikian dapat dideskripsikan bahwa efektifitas dan kapasitas kelembagaan Baznas, UPZ dan LAZ berdasarkan perspektif efektifitas dan kapasitas kelembagaan sudah cukup memadai.

\section{- Efektifitas dan Kapasitas Kebijakan/regulasi}

Pengelolaan zakat di Kota Serang diatur melalui Perda Nomor 6 tahun 2014 tentang pengelolaan zakat. Hasil penelitian menunjukkan bahwa implementasi pengelolaan zakat di di Kota Serang sudah melibatkan partisipasi masyarakat dan berjalan sesuai dengan regulasi, akan tetapi secara implementatif Perda tersebut belum mampu menjadi instrument yang dapat menyelesaikan permasalahan zakat secara komprehensif, penyebabnya adalah karena Perda Kota Serang Nomor 6 tahun 2014 tentang pengelolaan zakat masih mengacu kepada Undang-undang Nomor 38 tahun 1999 tentang pengelolaan zakat, sedangkan undang-undang yang sekarang berlaku adalah Undangundang Nomor 23 tahun 2011 (Mediatama, 2019) meskipun peneliti berpandangan bahwa secara umum
Perda tersebut sudah sesuai dan mengacu kepada UU Nomor 23 tahun 2011. Secara umum latar belakang dan pertimbangan Undang-undang Nomor 23 tahun 2011 tentang pengelolaan zakat adalah

a. bahwa negara menjamin kemerdekaan tiap-tiap penduduk untuk memeluk agamanya masingmasing dan untuk beribadat menurut agamanya dan kepercayaannya itu;

b. bahwa menunaikan zakat merupakan kewajiban bagi umat Islam yang mampu sesuai dengan syariat Islam;

c. bahwa zakat merupakan pranata keagamaan yang bertujuan untuk meningkatkan keadilan dan kesejahteraan masyarakat;

d. bahwa dalam rangka meningkatkan daya guna dan hasil guna, zakat harus dikelola secara melembaga sesuai dengan syariat Islam;

e. bahwa Undang-Undang Nomor 38 Tahun 1999 tentang Pengelolaan Zakat sudah tidak sesuai dengan perkembangan kebutuhan hukum dalam masyarakat sehingga perlu diganti;

f. bahwa berdasarkan pertimbangan tersebut perlu membentuk UndangUndang tentang Pengelolaan Zakat;

Aspek regulasi menjadi penting dalam mendorong kinerja kelembagaan yang efektif. Adanya undang-undang Nomor 23 tahun 2011 dan Perda Kota Serang Nomor 6 tahun 2014 tentang pengelolaan zakat secara implementatif 
Jurnal Administrasi Negara

ISSN : 2598-4039 (Online)

ISSN : 2302-2231 (Print)
Muhammad Kamil Husain

Universitas Serang Raya menjadi dasar hukum legalitas penerimaan zakat.

- Efektifitas dan Kapasitas Perubahan Sistem Implementasi

Hasil penelitian menunjukkan bahwa dari segi perubahan system implementasi, Perda Kota Serang Nomor 6 Tahun 2014 tentang pengelolaan zakat sudah mencakup berbagai dimensi yang dapat mendukung keberhasilan penerimaan zakat di Kota Serang. Hanya permasalahan yang dihadapi adalah masih rendahnya tingkat kesadaran masyarakat sehingga tujuan utama zakat untuk pemerataan kesejahteraan dan perubahan perilaku sehat belum tercapai (Husain et al., 2018). Di sisi lain, pengelolaan dan penyaluran zakat yang dilakukan dengan tata kelola yang baik dan benar juga memiliki implikasi positif bagi pemberdayaan masyarakat.

Kredibilitas lembaga zakat dipengaruhi oleh persepsi pengguna jasa yaitu, pertama, ada pembayar zakat yang membayar zakat dan berharap dana yang dibayarkan akan tersalurkan dengan baik; kedua, ada penerima zakat yang menerima dana dan berharap mendapatkan dana zakat yang cukup (Faisol Ibrahim, 2014). Implementasi sistem zakat yang efektif dan didukung kapasitas memadai dapat memainkan peran penting dalam mendukung pembangunan ekonomi yang berkelanjutan dan memfasilitasi kondisi keuangan yang lebih baik. Bahkan secara konseptual, pengembangan sistem zakat dinilai dapat melengkapi program pemerintah dalam pengentasan kemiskinan (Khasandy et al., 2019).

\section{- Kapasitas dan Derajat Perubahan kelompok sasaran}

Zakat merupakan salah satu mekanisme untuk memperkuat kemandirian ekonomi umat Islam selain sedekah dan wakaf (Takril \& Othman, 2020). Dalam hal ini efisiensi lembaga zakat melalui pendistribusian dana secara adil dan merata kepada penerima (Ahmad et al., 2015) sekaligus memberikan prioritas kepada perubahan derajat kelompok sasaran. Peningkatan kepercayaan cenderung mengarah pada peningkatan komitmen, sedangkan temuan lebih lanjut menunjukkan peran mediasi dari komitmen dalam hubungan antara kepercayaan dan perilaku memberi (Sargeant \& Lee, 2004)

Hasil penelitian menunjukkan bahwa derajat perubahan kelompok sasaran penerima zakat di Kota Serang berada pada kategori yang cukup baik meskipun masih belum produktif. Meskipun penanggulangan kemiskinan menjadi tujuan penting akan tetapi hal tersebut bukanlah tugas yang mudah. Dalam konteks jangka pendek, memberikan bantuan uang tunasi cukup efektif akan tetapi dapat menimbulkan ketergantungan kepada pemerintah atau Lembaga zakat. Oleh sebab itu perubahan paradigma dengan mengubah pemberian bantuan dapat dilakukan seperti memberikan bantuan 
Jurnal Administrasi Negara

ISSN : 2598-4039 (Online)

ISSN : 2302-2231 (Print)
Muhammad Kamil Husain

Universitas Serang Raya
Pendidikan anak-anak kelompok sasaran, bantuan fasilitasi kelompok sasaran ke pusat keterampilan dapat menjadi opsi bagi pemerintah di masa yang akan datang.

Pendekatan peningkatan kapasitas ini merupakan cara efektif untuk mengubah kondisi masyarakat miskin dari penerima zakat menjadi orang yang membayar zakat (Ab Rahman et al., 2012). Menurut (Ali \& Hatta, 2014) zakat dapat menjadi salah satu mekanisme dan pekerjaan sosial dalam praktik membantu masyarakat untuk mengatasi kemiskinan dan melakukan perubahan sosial di tingkat komunitas, organisasi, dan internasional.

\section{PENUTUP}

Zakat dalam berbagai aspek berperan penting merubah kondisi sosial dan ekonomi masyarakat. Oleh sebab itu efektifitas dan kapasitas kelembagaan, kebijakan/regulasi, perubahan system implementasi dan derajat perubahan kelompok sasaran menjadi sangat penting sebagai indikator-indikator pencapaian tujuan zakat secara keseluruhan.

Dalam konteks regulasi, Peraturan Daerah Kota Serang Nomor 6 tahun 2014 berdasarkan efektifitas dan kapasitas sudah cukup memadai dan menjadi instrument penting penerimaan zakat meskipun diperlukan penguatan pada aspek kelembagaan dan inovasi pengumpulan dan distribusi zakat yang efektif dan produktif. Selain itu dalam implementasinya, kapasitas konten Perda sudah mengatur penyelenggaraan zakat dengan melibatkan partisipasi masyarakat.

Rekomendasi penelitian ini adalah mendorong perubahan Perda yang dapat mendukung inovasi pelaksanaan pengumpulan, pendistribusian, dan pendayagunaan zakat serta dalam jangka Panjang mengoptimalkan kelompok sasaran melalui pemberian bantuan pendidikan anak-anak kelompok sasaran dan memfasilitasi kepala keluarga kelompok sasaran ke pusat keterampilan. 
Jurnal Administrasi Negara

ISSN : 2598-4039 (Online)

ISSN : 2302-2231 (Print)
Muhammad Kamil Husain

Universitas Serang Raya

\section{Referensi}

Ab Rahman, A., Alias, M. H., \& Omar, S. M. N. S. (2012). Zakat institution in Malaysia: Problems and issues. Global Journal Al-Thaqafah, 2(1), 3541.

https://doi.org/10.7187/GJAT122012. 02.01

Adiwijaya, Z. A., \& Suprianto, E. (2020). Good Governance of Zakat Institutions: a Literature Review. Journal of Southwest Jiaotong University, 55(2), 1-7. http://jsju.org/index.php/journal/art icle/view/561

Ahmad, R. A. R., Othman, A. M. A., \& Salleh, M. S. (2015). Assessing the Satisfaction Level of Zakat Recipients Towards Zakat Management. Procedia Economics and Finance, 31(15), 140-151. https://doi.org/10.1016/s22125671(15)01141-7

Ali, I., \& Hatta, Z. A. (2014). Zakat as a poverty reduction mechanism among the muslim community: Case study of Bangladesh, Malaysia, and Indonesia. Asian Social Work and Policy Review, 8(1), 59-70. https://doi.org/10.1111/aswp.12025

Bakvis, H. (2000). Country report: Rebuilding policy capacity in the era of the fiscal dividend: A report from Canada. Governance, 13(1), 71-103. https://doi.org/10.1111/09521895.00124

Bremer, J. (2013). Zakat and Economic
Justice: Emerging International Models and their Relevance for Egypt. Third Annual Conference on Arab Philantrophy and Civic Engagement, 51-74.

Faisol Ibrahim, M. (2014). Sistem Pengurusan Zakat di Malaysia: Analisis Strategi Penyebaran Maklumat Menerusi Laman Sesawang. Jurnal Pengurusan, 42(2), 119-130.

https://doi.org/10.17576/pengurusa n-2014-42-10

Howlett, M., \& Lindquist, E. (2014). Policy Analysis and Governance: Analytical and Policy Styles in Canada. Journal of Comparative Policy Analysis: Research and Practice, 6(3), 225-249.

https://doi.org/10.1080/13876980420 00305194

Husain, M. K., Malik, A., \& Wahyuni, S. (2018). Distribution of Productive Zakat to Improve the Welfare of Rural Community in Banten Through Movement of Healthy Living Behavior Programs. Proceeding The 2nd International Symposium on Islamic Epistemology, 45.

Khasandy, Aisha, E., \& Badrudin, R. (2019). Munich Personal RePEc Archive The Influence of Zakat on Economic Growth and Welfare Society in Indonesia The Influence of Zakat on Economic Growth and Welfare Society in. MPRA (Munich Personal RePEc Archive), 3(1), 65-79. 
Jurnal Administrasi Negara

ISSN : 2598-4039 (Online)

ISSN : 2302-2231 (Print)
Muhammad Kamil Husain

Universitas Serang Raya
Lubis, M., \& Azizah, A. H. (2018). Preface. In Towards Achieving the Efficiency in Zakat Management System: Interaction Design for Optimization in Indonesia (Vol. 886, Nomor January). Springer Singapore.

https://doi.org/10.1007/978-981-131628-9

Mediatama, D. (2019). Dinilai Tak Relevan, Baznas Minta Perda Pengelolaan Zakat Diperbaharui. Digdaya Mediatama. https://digdayamedia.id/dinilai-takrelevan-baznas-minta-perdapengelolaan-zakat-diperbaharui/ (Diakses pada tanggal 02 September 2020)

Noor, A. H. M., Rasool, M. S. A., Ali, R. M. Y. S. M., \& Rahman, R. A. (2015). Efficiency of Islamic Institutions: Empirical Evidence of Zakat Organizations' Performance in Malaysia. Journal of Economics, Business and Management, 3(2), 282286.

https://doi.org/10.7763/joebm.2015. v3.195

Qardhawi, Yusuf, Terjemahan Harun et al. cet kelima (1999), Bogor, Pustaka Literasi antar Nusa, 879.

Quthub, Sayyid, Tafsir Fi Dzilalil Qur'an (1992), Kairo, Dar Syuruq, 81

Said, J., Ghani, E. K., Zawawii, S. N. H., \& Yusof, S. N. S. (2012). Composite Performance Measurement for Zakat Organisations. British Journal of Economics, Finance and
Management Sciences, 4(1), 50-58.

Sandfort, J., \& Moulton, S. (2015). Effective Implementation in Practice: Integrating Public Policy and Management. John Wiley \& Sons.

Sargeant, A., \& Lee, S. (2004). Donor trust and relationship commitment in the U.K. charity sector: The impact on behavior. Nonprofit and Voluntary Sector Quarterly, 33(2), 185-202. https://doi.org/10.1177/08997640042 63321

Sururi, A. (2016). Inovasi Kebijakan Publik (Tinjauan Konseptual dan Empiris). Sawala, 4(3), 1-14.

Takril, N. F., \& Othman, N. F. (2020). Effectiveness of Zakat Collection and Distribution of Zakat counter at higher learning Institutions. International Journal of Islamic Economics and Finance Research, 3(2), 91-106.

Wahab, N. A., Zainol, Z., Abu Bakar, M., Ibrahim, A. Z., \& Minhaj, N. (2016). Developing service quality index for zakat institutions. International Journal of Economics and Financial Issues, 6(7Special Issue), 249-258.

Wu, X., Ramesh, M., \& Howlett, M. (2015). Policy capacity: A conceptual framework for understanding policy competences and capabilities. Policy and Society, 34(3-4), 165-171. https://doi.org/10.1016/j.polsoc.2015 .09 .001 